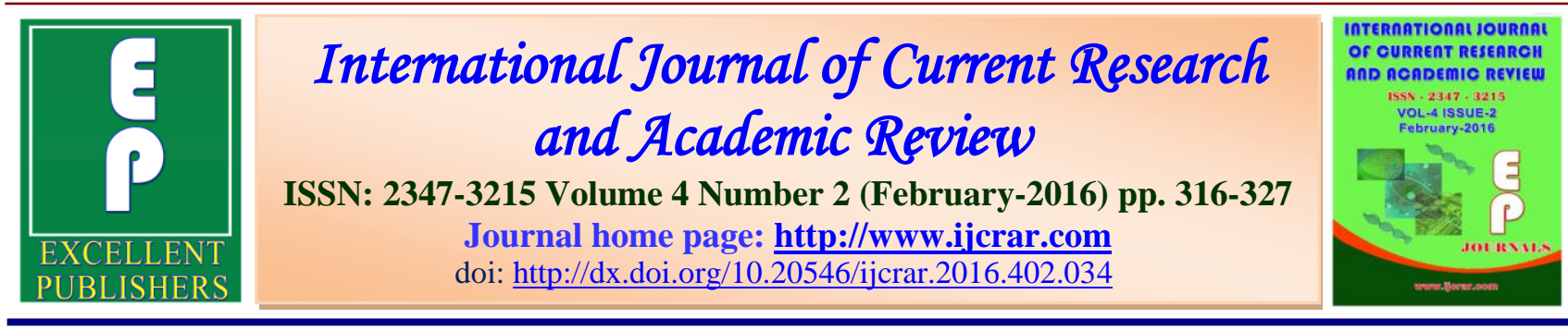

\title{
ATPases in the colon of rats fed a Nigerian like diet supplemented with folate and bitter leaf (Vernonia amygdalina)
}

\author{
Augusta inegbedion $^{1^{*}}$ and George E. Eriyamremu ${ }^{2}$ \\ ${ }^{1}$ Department of Medical Biochemistry, College of Medicine, Ambrose Ali University, \\ Ekpoma, Edo State, Nigeria \\ ${ }^{2}$ Department of Biochemistr y, Faculty of Life Sciences, University of Benin, Benin City, Edo \\ State, Nigeria
}

*Corresponding author

\section{KEYWORDS}

Folate and

bitter leaf,

Vernonia

Amygdalina,

ATPases,

colon

carcinogenesis
A B S T R A C T

This study examined the effect of a wholly compounded Nigerian-like diet supplemented with folic acid and bitter leaf (Vernonia amygdalina) on the activity of ATPases in early colon carcinogenesis. It was also aimed to determine if any of the observed effect(s) of folic acid and bitter leaf is/are potentiated before the onset of colon carcinogenesis or also occur during the process. One hundred and twenty eight Wistar albino rats of $120 \mathrm{~g} \pm 0.3 \mathrm{~g}$ were used for this study and were divided into two groups. Animals in the first group were fed with the wholly compounded food supplemented with folic acid and bitter leaf before being exposed to Cycads for two weeks (the pretreated rats) while animals in the second group were fed with Cycads for two weeks before they were exposed to the wholly compounded food supplemented with folic acid and bitter leaf (the post-treated rats). The animals in each group were sub-divided into two diet classes. Animals in one group were fed with wholly compounded normal diet (ND) which served as the control class while animals in the second group were fed with wholly compounded Nigerian-like diet (NLD) which was low in protein and fat but high in carbohydrate and fiber, The animals in each diet class were further distributed into four subgroups. In each subclass, one group received the diet alone, another group received the diet and folic acid, and another group received the diet and bitter leaf, while the fourth group received the diet, folic acid and bitter leaf. The animals were given food and water ad libitum and were force fed with folic acid, bitter leaf and cycads. Such that they consumed $0.5 \mathrm{mg} / \mathrm{kg}$ body weight of folic acid, bitter leaf and Cycads. Exposing the colon of rats to bitter leaf and folic acid significantly $(\mathrm{P}<0.05)$ increased the activity of $\mathrm{Na}^{+}-\mathrm{K}^{+}$ATPase but significantly $(\mathrm{P}<0.05)$ decreased magnesium ATPase activity and calcium ATPase activity. These results suggest that folic acid and bitter leaf (Vernonia amygdalina) may protect against colon cancer before and after its onset. 


\section{Introduction}

$\mathrm{Na}^{+} / \mathrm{K}^{+}$ATPase, $\quad \mathrm{Mg}^{2+}$ ATPase and $\mathrm{Ca}^{2+}$ ATPase are membrane bound enzymes responsible for the transport of sodium/potassium, magnesium and calcium ions across the cell membrane at the expense of ATP by hydrolysis (Sudhandiran, 2013). They have been implicated in the regulation of many cellular functions including cell volume regulation, regulating the osmotic balance of the cell and maintaining high concentration of intra-cellular ions. Numerous studies have now established that the influx of ions across the plasma membrane into the cell is a key trigger or regulator of cellular processes relevant to tumor progression, including proliferation, migration, and apoptosis (Monteith et al, 2012).

Cancer is considered to be a group of diseases of multiple causes which occurs when cells become abnormal and divide without control or order (American Cancer Society, 1990). The development of cancer is referred to as carcinogenesis and the carcinogenic processes involve multiple steps (Sugimura, 1992). Cancer is a leading cause of death worldwide and the incidence of cancer is on the increase in every country of the world (Jemal et al, 2010 ; Bray et al, 2013). This increase, coupled with the harsh side effects of some of the cancer chemotherapy, has led to the search for more natural biological products, especially those derived from plant products. One of such plants with proven anti-breast cancer activity is Vernonia amygdalina (Izevbigie, 2003).

Vernonia amygdalina (commonly called Bitter Leaf) is one of the edible vegetables in Nigeria and other parts of African sub region. It is a shrub or tree which grows to about five meters high especially around forest margins and grows wild under severe anthropogenic and environmental pressures (Khalafalla et al, 2009). The full binomial name is Vernonia amygdalina Del (Farombi and Nwoye, 2011). In Nigeria where the plant is found in abundance, it performs both medicinal and nutritive functions. It is reported to be a medicinal plant for diabetes and fever (Crellin et al, 1989). It is used in the prevention of malaria fever, elimination of worms, treatment of stomach upset, induction of fertility in barren women and treatment of diabetic mellitus (Igile et al, 1995).

A root infusion is taken in Nigeria as a worm expeller as well as for intestinal parasitic infections. Chimpanzees have been observed to ingest the leaves when suffering from parasitic infections (Huffman and Koshimizu 1993). Vernonia amygdalina have been used for ingivitis and toothache due to its proven antimicrobial activity (Ademola and Eloff, 2011). It has been found to be effective as blood purifier, uterus toner and helps also to prevent atherosclerosis (Nwanjo, 2005; Erasto et al, 2006). Vernonia amygdalina is well known for producing anticancer agent, vernodaline and vernolide (Khalafalla et al, 2009). Imaga and Bamigbetan, (2013) concluded in their study that aqueous extract of Vernonia amygdalina is safe for consumption as food or as herbal medicine without plausible toxicity to body organs and tissues.

In this present study the effect of a wholly compounded Nigerian-like diet supplemented with folic acid and bitter leaf (Vernonia amygdalina) on the activity of ATPases in early colon carcinogenesis was examined. It also examined if any of the observed effect(s) of folic acid and bitter leaf is/are potentiated before the onset of colon carcinogenesis or also occur during the process. 


\section{Materials and Methods}

\section{Experimental Animals}

Wistar albino rats of $120 \pm 0.3 \mathrm{~g}$ purchased from the animal house of Ambrose Ali University, Ekpoma, Edo state, were used for this study. The rats were weighed and assigned comparable weights in all groups $( \pm 0.3 \mathrm{~g})$. The animals were acclimatized with their respective diets for a period of one week. The cages housing the rats were kept in an environment with free supply of air and light. Water and feed were changed daily.

\section{Feed}

The leaves of the plant cycads Circinalis were obtained from Santua garden, Ugbowo, Benin City, Edo state. The leaves of bitter leaf (Vernonia amygdalina) were obtained from Ekpoma express market, Ekpoma, Edo state. Both leaves were identified at botany department, Ambrose Ali University, Ekpoma. The vitamin mix was from vitadol. The soya beans, white garri, sugar and palm oil were obtained from Ekpoma express market, Ekpoma, Edo state. While the folic acid was obtained from Jofel pharmacy, Ekpoma, Edo state.

The leaves of cycads and bitter leaf (Vernonia amygdalina) were washed and dried in the oven at $50^{\circ} \mathrm{C}$ and then blended into powder. The soya beans were cooked for about five hours, dried in the oven at $60^{\circ} \mathrm{C}$ and blended into powder. The other food components which were already in powder form were mixed in their various proportions as shown in table 1. The ND was prepared by mixing together $44 \mathrm{~g}$ of blended soya beans, $32.5 \mathrm{~g}$ of white garri, $3 \mathrm{ml}$ of palm oil, $2 \mathrm{~g}$ of powdered vitamin mix, $13 \mathrm{~g}$ of sugar, and $1.5 \mathrm{~g}$ of fiber while the NLD was prepared by mixing together $27 \mathrm{~g}$ of blended soya beans, $40 \mathrm{~g}$ of white garri, $1 \mathrm{ml}$ of palm oil, $2 \mathrm{~g}$ of powdered vitamin mix, $5 \mathrm{~g}$ of sugar, and $10 \mathrm{~g}$ of fiber. The normal diet (ND) was patterned after previously fed diets by Schuette and Richard (1986) in their study of the effects of diets high in fats and/or fiber on colonic absorption of dimethylhydrazine (DMH) in rats. The diet rich in carbohydrate and fiber was patterned after that of Anderson and Gustafson (1987) in their study of the hypolipidaemic effect of a high carbohydrate and high fat diet.

\section{Isolation of Colon}

At the end of the twelve weeks of feeding, all the rats were weighed and starved overnight. Subsequently, they were sacrificed after sedating with chloroform and then dissected accordingly. The colon (first $10 \mathrm{~cm}$ of the proximal end of the large intestine) was recovered from each rat and flushed several times with ice cold normal saline $(0.9 \% \mathrm{NaCl}$ solution) until free of debris. It was inverted and the mucosa was removed by scrapping with a glass slide. The tissue and mucosa were kept separately in sample bottles $(10 \mathrm{~mL})$ and stored at $-4^{0} \mathrm{C}$ for analysis.

\section{Preparation of Sample}

$1 \mathrm{~g}$ of colon tissue and mucosa of each rat was homogenized separately in $9 \mathrm{ml}$ of $0.9 \%$ Nacl solution for 10 seconds. The homogenate was subsequently centrifuged at $10,000 \mathrm{rpm}$ for $15 \mathrm{minutes}$ at $4^{\circ} \mathrm{C}$. The supernatant was used as source of sample for biochemical analysis.

\section{Biochemical Assay}

\section{Estimation of ATPases Activity}

\section{Estimation of Calcium ATPase Activity}

The reaction mixture contained $1.5 \mathrm{ml}$ of $160 \mathrm{mM}$ Tris $\mathrm{HCl}$ cofactor. 0.3mM ATPase 
solution was added and incubated for 1 minute. The reaction was started by the addition of $0.2 \mathrm{ml}$ of the enzyme extract (supernatant from homogenate). The final mixture was $2.0 \mathrm{ml}$. The mixture was further incubated for 10 minutes, $0.1 \mathrm{ml}$ of supernatant was taken for inorganic (Pi) determination. $2 \mathrm{ml}$ of ammonium molybdate were added followed by $2 \mathrm{ml}$ of $0.2 \%$ ascorbic acid. The colour developed was read immediately (within 1 minute) using the spectrophotometer at $625 \mathrm{~nm}$. Protein determination was carried out using Lowry's method.

\section{Specific Activity of ATPase}

The activity of ATPase was estimated from the following expression.

Specific activity $=\quad$ Pi $\times 1 \times 4 \times 1$

$$
10 \times 31 \times 0.1 \times
$$

mg protein

$\mathrm{Pi}=$ inorganic phosphate obtained from standard curve.

$4=$ Total volume of reaction mixture

$0.1=$ Mixture of dilution of enzyme extract that was taken for the estimation of $\mathrm{Pi}$ after precipitation.

$31=$ Molar extinction of phosphorus

$10=$ incubation time

\section{Estimation of Magnesium ATPase Activity}

The above protocol was repeated for each sample except that of Tris buffer $\mathrm{PH} 7.4$ which contains only $5 \mathrm{mM} \mathrm{MgCl}_{2}$ as cofactor. The amount of inorganic phosphate (Pi) released in each case was extrapolated from the standard calibration curve. Protein determination was also carried out using the method of Lowry et al, (1951).

\section{Estimation of Sodium-Potassium ATPase Activity}

The sodium-potassium ATPase was gotten by subtracting the magnesium ATPase activity from total ATPase .

\section{Estimation of Total ATPase Activity}

$1.5 \mathrm{ml}$ of $50 \mathrm{mM}$ tris $\mathrm{HCl}$ buffer containing the cofactors $\mathrm{PH} 7.4$ and $0.3 \mathrm{ml}$ of $5 \mathrm{mM}$ ATP solution were added into a test tube and incubated for 1 minute. The reaction was started by addition of $0.2 \mathrm{ml}$ of the enzyme extract (Supernatant from homogenate). The final volume of the mixture was $2.0 \mu 1$. The mixture was further incubated for 10 minutes and terminated by the addition of $2 \mathrm{ml}$ of $10 \%$ trichloroacetic acid. After centrifugation at $1000 \mathrm{rpm}$ for 10 minutes, the supernatant was collected and used for inorganic phosphate determination. The above process was repeated for every sample.

\section{Inorganic Phosphate Determination (pi)}

The supernatant $(0.1 \mathrm{ml})$ above was taken and used for inorganic phosphate determination. $2 \mathrm{ml}$ of ammonium molybdate were added followed by $2 \mathrm{ml}$ of $0.2 \%$ ascorbic acid. The colour developed was read immediately within 1 minute at $625 \mathrm{~nm}$.

\section{Protein Content Estimation}

$0.1 \mathrm{ml}$ of the supernatant was added to the respective test tube except the blank and made up to $4.5 \mathrm{ml}$ with distilled water. $5 \mathrm{ml}$ of alkaline reagent were added and allowed to stand for 15 minutes at room temperature. $0.5 \mathrm{ml}$ of folin ciocalteau was then added to the reaction mixture and allowed to stand for 30 minutes at room temperature for the colour to develop. The absorbance was read at $750 \mathrm{~nm}$ against reagent blank. 


\section{Statistical Analysis}

Statistical analysis was carried out using computer SPSS software.

\section{Results and Discussion}

Results are as presented in figures 1-12. Results showed that bitter leaf and folic acid significantly $(\mathrm{P}<0.05)$ increased the activity of $\mathrm{Na}^{+}-\mathrm{K}^{+}$ATPase but significantly $(\mathrm{P}<0.05)$ decreased magnesium ATPase activity and calcium ATPase activity

$\mathrm{Na}^{+}-\mathrm{K}^{+}$ATPase was observed with the inclusion of folic acid in the diets of animals. Increased activity of $\mathrm{Na}^{+}-$ $\mathrm{K}^{+}$ATPase was also observed with the inclusion of bitter leaf in the diets of animals. This could be due to the antioxidant property they possess. They are able to scavenge free radicals that would have caused damage to the cell membrane. This implies that more sodium ion enters in to the colonic lumen making the colonic cells more viable. This result agrees with previous reports by Josiah et al, (2012) and Atangwho et al, (2007).
Decreased activity of magnesium ATPase was observed with the inclusion of folic acid and bitter leaf separately in the diets of animals. This implies less influx of magnesium into the cell. Very many enzymes and ion transport require magnesium and it plays a role in fatty acid and phospholipid metabolism, thus affecting permeability and stability of membranes. Magnesium ATPase is closely tied to the energy generation of oxidative phosphorylation of the mitochondria. The reduce magnesium ATPase activity implies less dependence on the oxidative phosphorylation for energy in these animals. This argument cannot be over emphasized in light of study which relate high intake of magnesium to low cancer risk. Studies by Molena-Montes et al, (2012) show that increased intake of magnesium is associated with reduced risk of pancreatic cancer. As folic acid and the bitter leaf reduced magnesium ATPase, it would invariably reduce the level of magnesium that enters the colonic mucosa or the tissue.

Table.1 Composition of Experimental Diet

\begin{tabular}{|l|l|l|l|l|l|l|l|l|}
\hline $\begin{array}{l}\text { Dietary } \\
\text { Component }\end{array}$ & ND & NDB & NDF & NDBF & NLD & NLDB & NLDF & NLDBF \\
\hline $\begin{array}{l}\text { Soya beans } \\
\text { (protein) (g) }\end{array}$ & 44 & 44 & 44 & 44 & 27 & 27 & 27 & 27 \\
\hline $\begin{array}{l}\text { White garri } \\
\text { (carbohydrate) (g) }\end{array}$ & 32.5 & 32.5 & 32.5 & 32.5 & 40 & 40 & 40 & 40 \\
\hline Palm oil (ml) & 3 & 3 & 3 & 3 & 1 & 1 & 1 & 1 \\
\hline Vitamin/salt (g) & 2 & 2 & 2 & 2 & 2 & 2 & 2 & 2 \\
\hline Sugar/sucrose (g) & 13 & 13 & 13 & 13 & 5 & 5 & 5 & 5 \\
\hline Fiber (g) & 1.5 & 1.5 & 1.5 & 1.5 & 10 & 10 & 10 & 10 \\
\hline Bitter leaf (g) & - & 0.5 & - & 0.5 & - & 0.5 & - & 0.5 \\
\hline Folic acid (g) & - & - & 0.5 & 0.5 & - & - & 0.5 & 0.5 \\
\hline Cycads (g) & 0.5 & 0.5 & 0.5 & 0.5 & 0.5 & 0.5 & 0.5 & 0.5 \\
\hline
\end{tabular}




\section{Int.J.Curr.Res.Aca.Rev.2016; 4(2): 316-327}

Figure.1 Sodium Potassium ATPase Activity in the Colonic Mucosa of Pre-Treated rats Fed with Cycads and Nigerian-like Folic Acid and Bitter Leaf Supplemented Diets

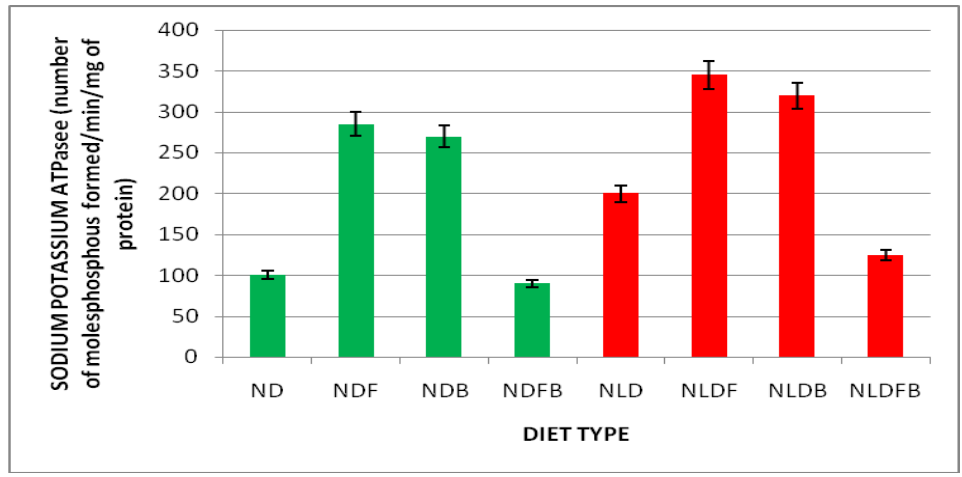

Figure.2 Sodium Potassium ATPase Activity in the Colonic Mucosa of Post-Treated Rats Fed with Cycads and Nigerian-like Folic Acid and Bitter Leaf Supplemented Diets

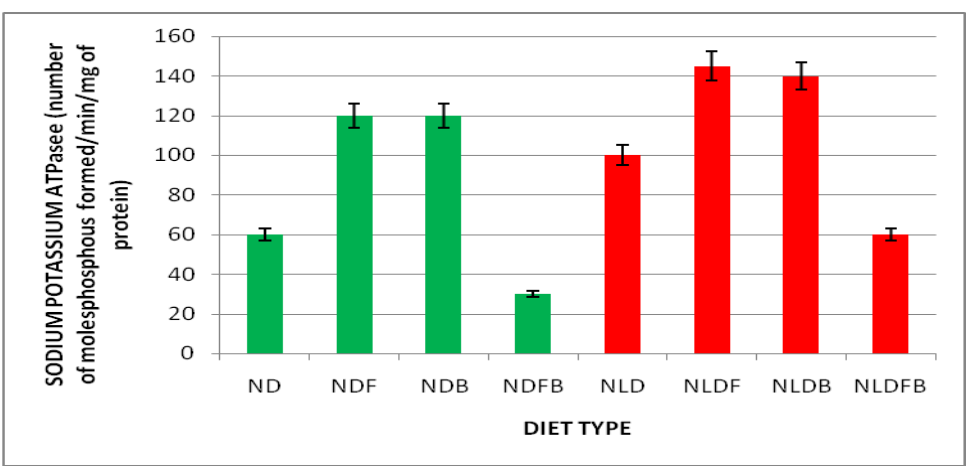

Figure.3 Sodium Potassium Activity ATPase in the Colonic Tissue of Pre-Treated Rats Fed with Cycads and Nigerian-like Folic Acid and Bitter Leaf Supplemented Diets

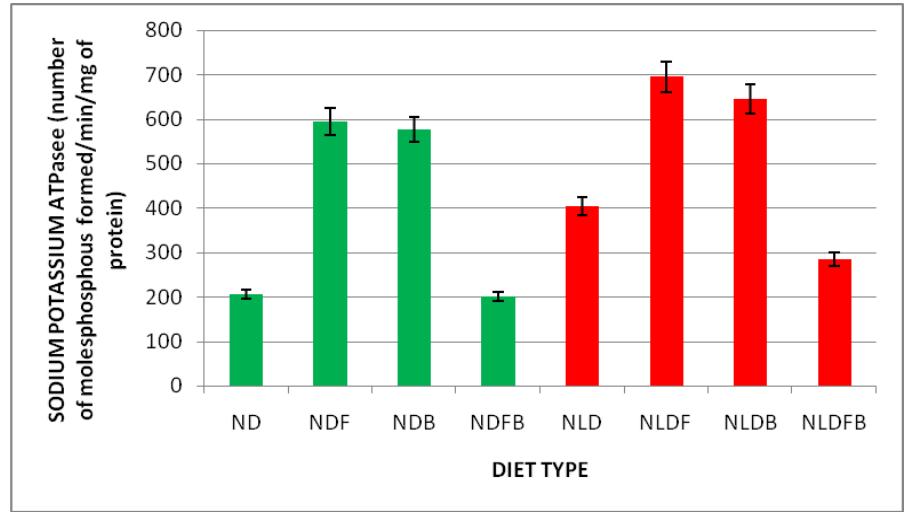




\section{Int.J.Curr.Res.Aca.Rev.2016; 4(2): 316-327}

Figure.4 Sodium Potassium ATPase Activity in the Colonic Tissue of Post-Treated Rats Fed with Cycads and Nigerian-like Folic Acid and Bitter Leaf Supplemented Diets

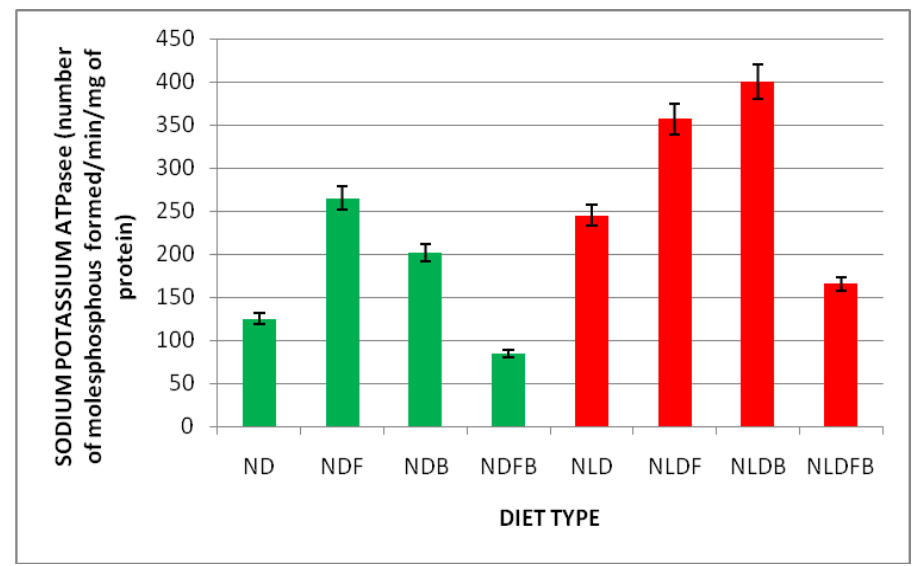

Figure.5 Magnesium ATPase Activity in the Colonic Mucosa of Pre- Treated Rats Fed with Cycads and Nigerian-like Folic Acid and Bitter Leaf Supplemented Diets

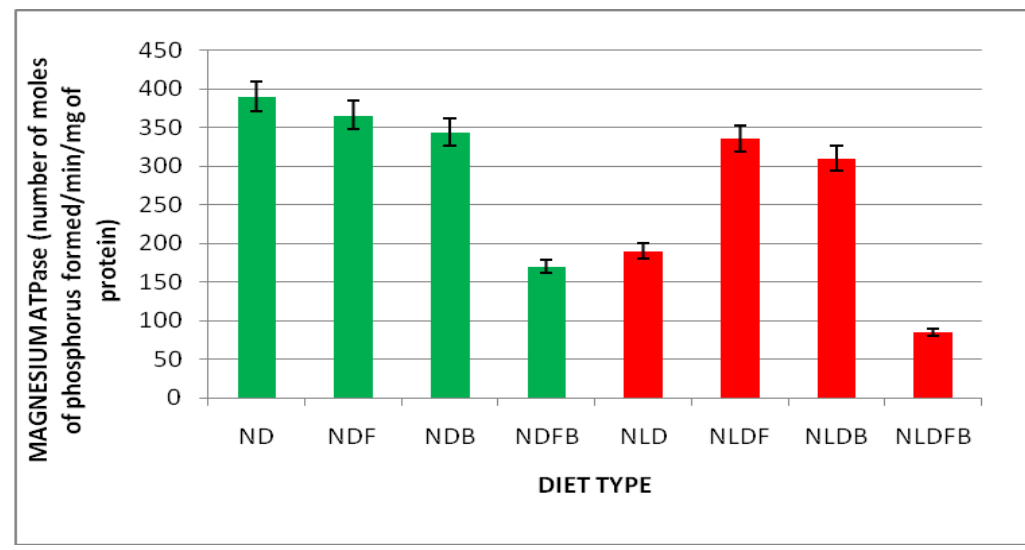

Figure.6 Magnesium ATPase Activity in the Colonic Mucosa of Post-Treated Rats Fed with Cycads and Nigerian-like Folic Acid and Bitter Leaf Supplemented Diets

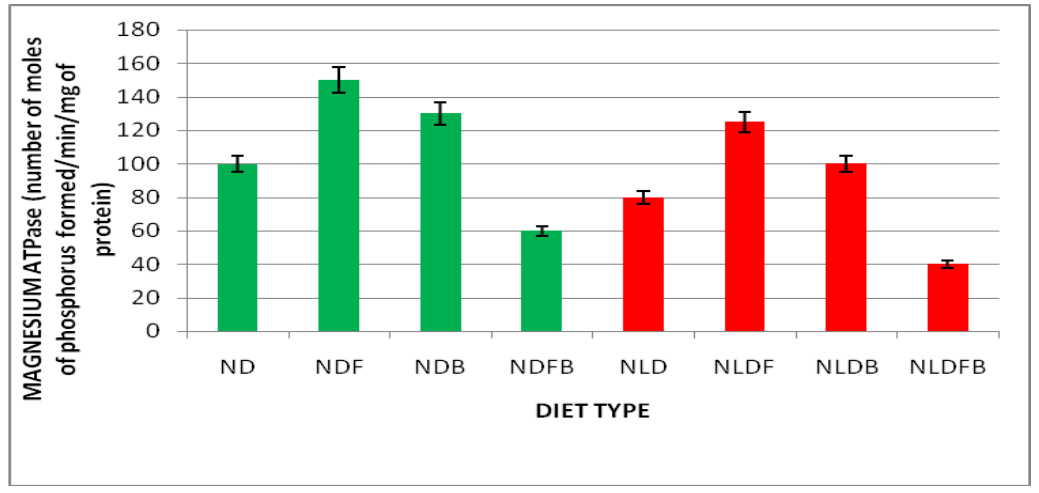


Int.J.Curr.Res.Aca.Rev.2016; 4(2): 316-327

Figure.7 Magnesium ATPase Activity in the Colonic Tissue of Pre-treated rat Fed with Cycads and Nigerian-like Folic Acid and Bitter Leaf Supplemented Diets

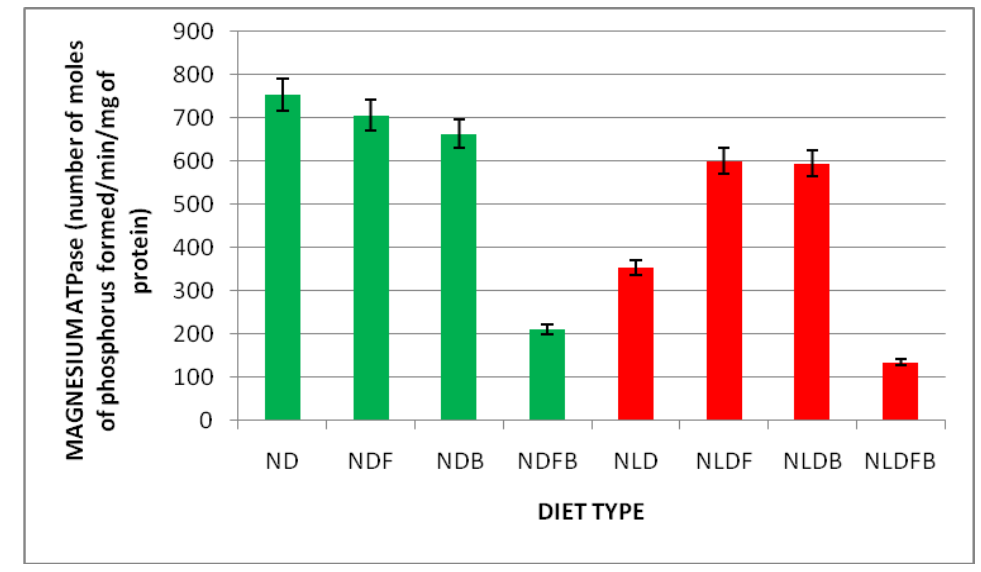

Figure.8 Magnesium ATPase Activity in the Colonic Tissue of Post-Treated Rats Fed with Cycads and Nigerian-like Folic Acid and Bitter Leaf Supplemented Diets

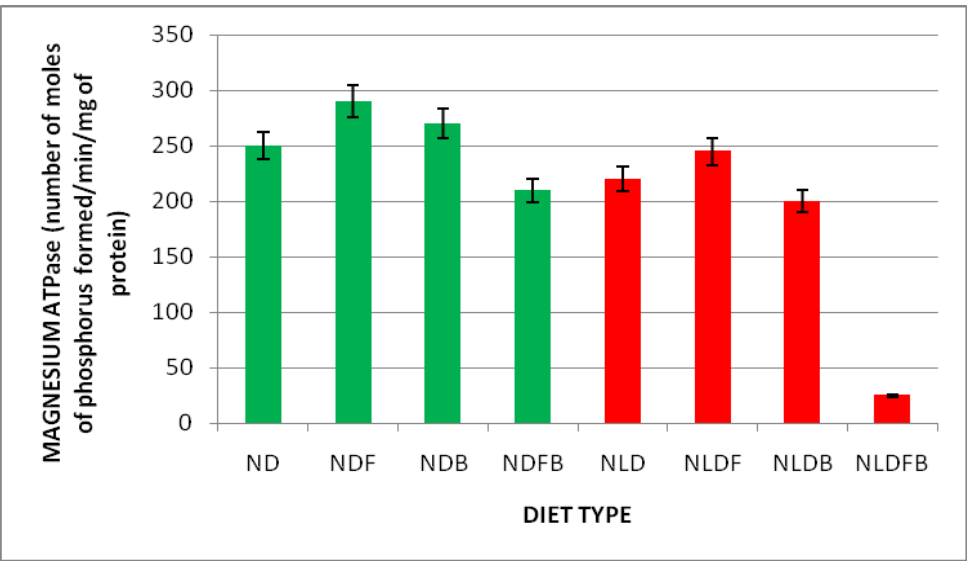

Figure.9 Calcium ATPase Activity in the Colonic Mucosa of Pre-treated Rats Fed with ycads and Nigerian-like folic Acid and Bitter Leaf Supplemented Diets

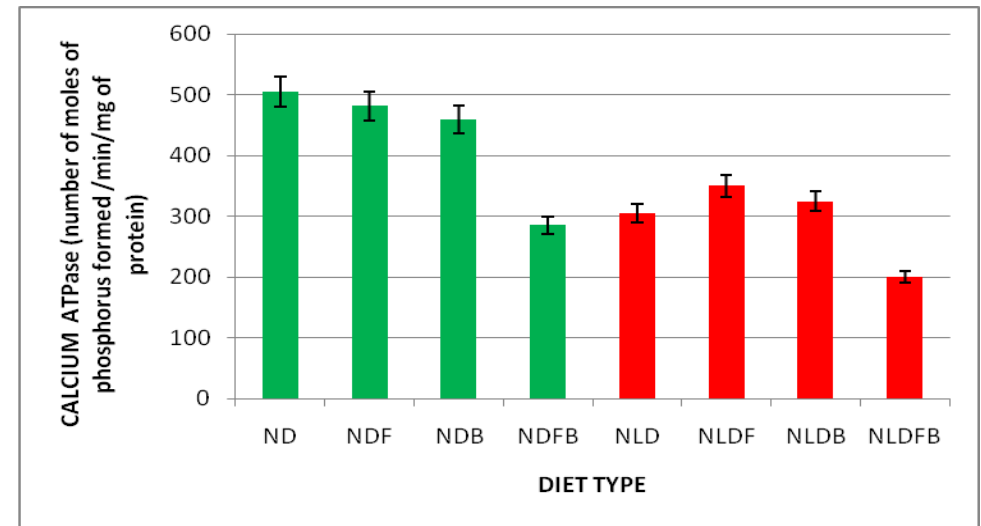


Figure.10 Calcium ATPase Activity in the Colonic Mucosa of Post-treated Rats Fed with Cycads and Nigerian-like Folic Acid and Bitter Leaf Supplemented Diets

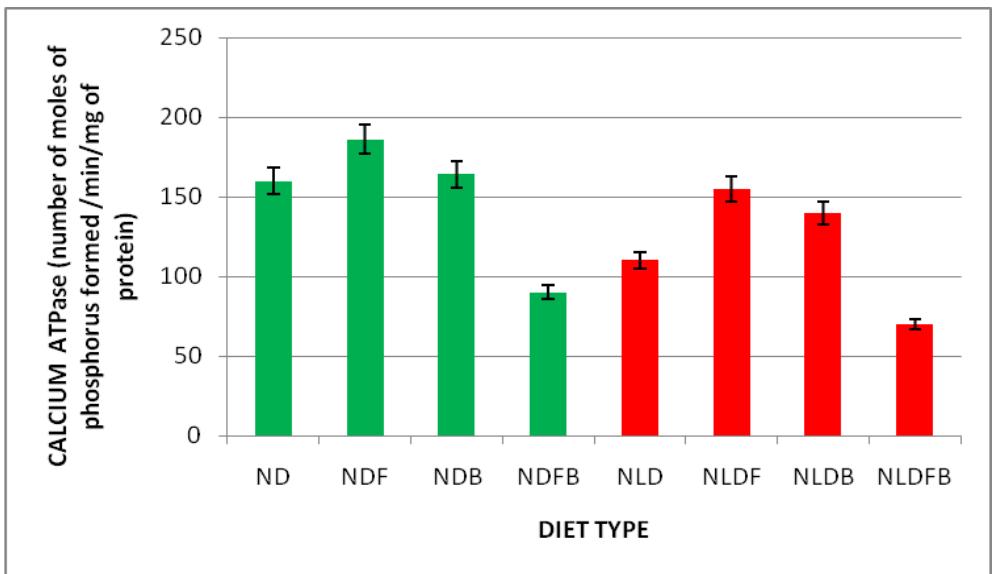

Figure.11 Calcium ATPase Activity in the Colonic Tissue of Pre-treated Rats Fed with Cycads and Nigerian-like Folic Acid and Bitter Leaf Supplemented Diets

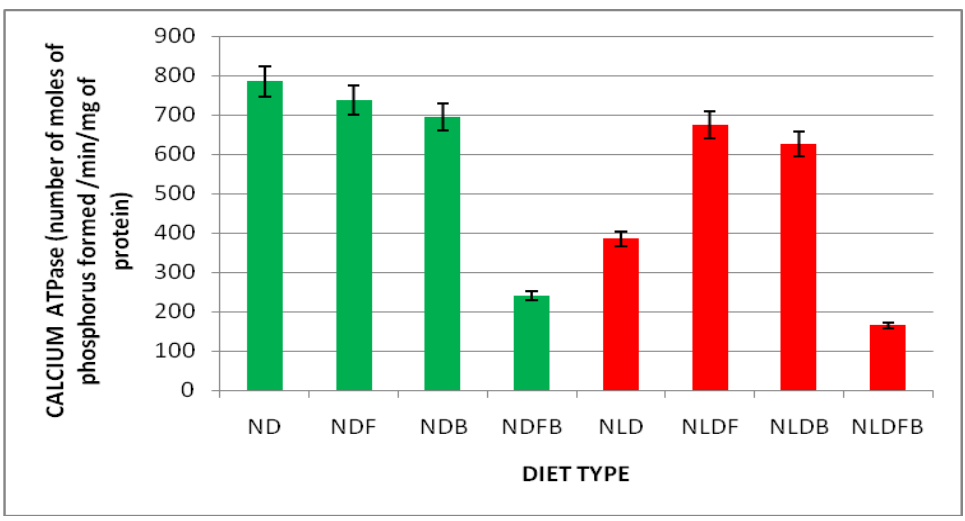

Figure.12 Calcium ATPase Activity in the Colonic Tissue of Post-Treated Rats Fed with Cycads and Nigerian-like Folic Acid and Bitter Leaf Supplemented Diets

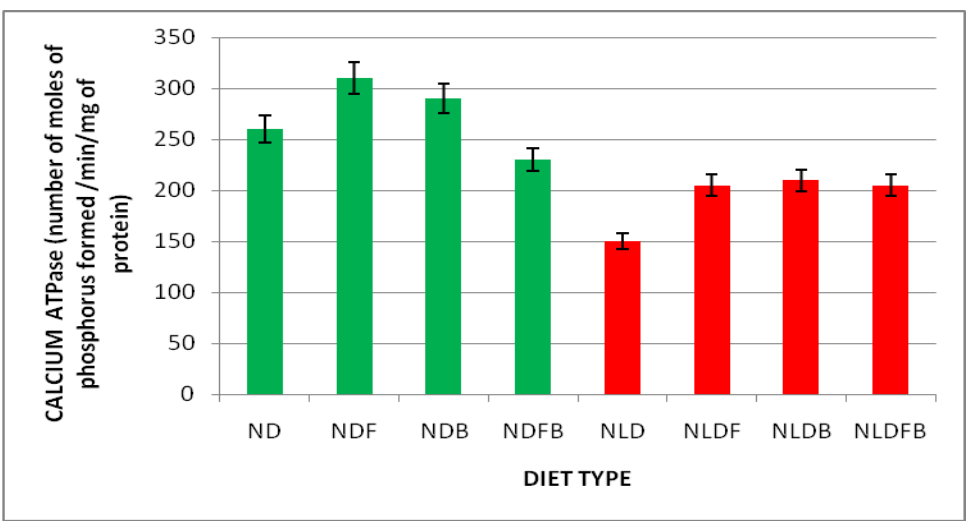


The NLD is high in fibre. High dietary fiber has been reported to decrease dietary calcium absorption. The result of this work agrees with the study of Ashton et al, (2007) who reported that calcium was reduced in low-protein rats. In this study however whole tissue calcium ATPase was assessed. It would be interesting to carry out the effect of folic acid and bitter leaf on organelle calcium ATPases. In a recent study, Sarco/endoplasmic reticulum calcium ATPase (SERCA) enzymes play important roles in several signal transduction pathways that control proliferation, differentiation and apoptosis. A report has shown that SERCA2 expression is positively correlated with tumor node metastasis and grades of patients with colorectal cancer ( $\mathrm{Lu}$ et al, 2014). The study reported similar findings in mice ( $\mathrm{Lu}$ et al, 2014). Besides, SERCA2 expression was also increased in undifferentiated HT29 cells as compared with that in differentiated HT-29 gal cells (Lu et al, 2014). Moreover, SERCA2 over expression promoted proliferation and migration of SW480 cells via activating MAPK and AKT signaling pathways, while silence of SERCA2 inhibited the proliferation and migration of SW480 cells (Lu et al, 2014).

\section{References}

Ademola, I. O and Eloff, J. N. (2011). Anthelminthic activity of acetone extract and of Vernonia amygdalina against Haemonchus contortus eggs and larvae. Trop. Anim. Health Prod. 43(2):521527.

American Cancer Society (1990). cancer facts and figures Atlanta, G.A

Anderson, J. W and Gustafson, N. J. (1987). High carbohydrate, high fiber diet. Is it practical and effective in treating hyperlipidemia? Postgrad. Med. 82:40-55.
Ashton, N; Al-Wasil, S.H; Bond, H; Berry,L. J; Denton, J and Freemont, J. A. (2007). The effect of a low-protein diet in pregnancy on offspring renal calcium handling. Am. J. Physiol. 293(2)759-765.

Atangwho, I. J; Ebong, P. E; Egbung, G. E; Eteng, M. U and Eyong, E. U. (2007). Effect of Vernonia amygdalina Del. on liver function in alloxan induced hyper glycemic rats J. Pharm. Bioresour. 4:25-31.

Atangwho, I. J; Ebong, P. E; Eteng, M.U; Eyong, E.U and Obi, A.U. (2007). Effects of Vernonia amygdalina (Del). leaf on kidney function of diabetic rats Int. J. Pharmacol. 3:143148.

Atangwho, I. J; Ebong, P.E; Eyong, E.U; Eteng, M.U; Uboh, F. E. (2007). Vernonia amygdalina (Del): a potential prophylactic anti-diabetic agent in lipids complication Glob. J. Pure Appl. Sci. 13:103-106.

Augustsson, K; Skog, K; Jägerstad, M; Dickman, P.W and Steineck, G. (1999). Dietary heterocyclic amines and cancer of the colon, rectum, bladder and kidney: a populationbased study. Lancet, 353, 703-707.

Bray, F; Ren, J.S; Masuyer, E; Ferlay, J. (2013). Estimates of global cancer prevalence for 27 sites in the adult population in 2008. Int. J. Cancer. 132(5):1133-1145.

Crellin, J. K; Philport, J and Tommie, B. (1989). A Reference Guide to Medicinal Plants: Herbal Medicine, Past and Present, Duke University press. p265.

Doll, R. and Peto, R. (1981). The causes of cancer: Quantitative estimates of avoidable risks of Cancer in the united states today. J. Natl. cancer. Inst. 66:1191-1208 
Erasto, P; Grierson, D.S and Afolayan, A. J. (2006). Bioactive sesquiterpene Lactones from the leaves of Vernonia amygdalina. J. Ethnopharmacol. 2006; 106: 117120.

Farombi, E.O. and Owoeye, O. (2011). Antioxidative and chemopreventive properties of Vernonia amygdalina and Garcinia biflavonoid. Int. J. Environ. Res. Public Health, 8: 25332555.

Huffman, M. A.and Koshimizu, K. (1993). Steroid glucosides from Vernonia amygdalina, a possible chimpanzee plant. Phytochem. (1993). 34: 409413.

Igile, G.O; Olesezk, W. Burda, S and Jurzysta, M. (1995). Nutritional Assessment of Vernonia amygdalina leaves in growing mice. J. Agric Food. Chem.43:2162-2166.

Imaga, N. O. A. and Bamigbetan, D. O. (2013). In vivo biochemical assessment of aqueous extracts of Vernonia amygdalina (Bitter leaf). Int. J. Nutr. and Metab.. 5(2):22-27.

Izevbigie, E.B. (2003). Discovery of watersoluble anticancer agents (edotides) from a Vegetable found in Benin City, Nigeria. Exp. Biol. Med., 228: 293298.

Jemal, A. R; Siegel, J; Xu and Ward, E. (2010). Cancer statistics, CA Cancer J. Clin.60: 277-300.

Josiah, S. J; Nwangwu, S. C. O; Akintola, A. A; Usunobun, U; Oyefule, F. Oyefule, S; Ajeigbe, O. K. and Akinola, A. (2012). Protective role of ethanolic extract of Vernonia amygdalina against Potassium Bromate induced tissue damage in Wistar Rats. Pakistan J. Nutr. 11: 5457.

Khalafalla M. M.; Eltayb A; Hussein, M. D; Amr A. N; Khalide, M. A; David, A. L; Alan, C and Hany, A. E. (2009).
Antileukemia activity from root cultures of vernonia amygdalina. J. Med. plants Res. 3 (8): 556-562.

Kritchevsky, D. (1992). Caloric restriction and experimental carcinogenesis. Adv. Exp. Med.Biol. 322: 134-141.

Lowry, O.H; Resebrough, N.J. Farra, A.L. and Randell, R.J. (1951). Protein measurement with the folin phenyl reagent. J.Biol.Chem.193:265-275.

Lu Fan; Li, A; Li, W; Cai, P; Yang, B; Zhang, M; Gu, Y; Shu, Y; Sun, Y; Shen, Y; $\mathrm{Wu}, \mathrm{X} ; \mathrm{Hu}, \mathrm{G} ; \mathrm{Wu}, \mathrm{X}$ and $\mathrm{Xu}, \quad \mathrm{Q}$. (2014). Novel role of Sarco/endoplasmic reticulum calcium ATPase 2 in development of colorectal cancer and its regulation by F36, a curcumin analog. Biomed. Pharmacotherapy. 68(8):1141-1148.

Molina-Montes, E; Wark, P. A; Sánchez, M. J; Norat, T; Jakszyn, P; LujanBarroso,L

Michaud, D. S; Crowe, F; Allen, N; Khaw, K. T; Wareham, N; Trichopoulou, A; Adarakis, G; Katarachia, H; Skeie, G; Henningsen, M; Broderstad, A. R; Berrino, F; Tumino, R; Palli, D; Mattiello, A; Vineis, P; Amiano, P; Barricarte, A; Huerta, J. M; Duell, E. J; Quirós, J. R; Ye, W; Sund, M; Lindkvist, $\quad$ B; Johansen, $\quad$ D; Overvad, K; Tjønneland, A; Roswall, N; Li, K; Grote, V. A; Steffen, A; Boeing, H; Racine, A; BoutronRuault, M. C; Carbonnel, F; Peeters, P. H; Siersema, P. D; Fedirko, V; Jenab, M; Riboli, E and Bueno-deMesquita, B. (2012). Dietary intake of iron, heme-iron and magnesium and pancreatic cancer risk in the European prospective investigation into cancer and nutrition cohort. Int. J. Cancer. 131(7):E1134-E1147.

Monteith, G. R; Davis, F. M. and RobertsThomson, S. J. (2012). Calcium Channels and Pumps in Cancer: 
Changes and Consequences. J. Biol. Chem. 287(38): 31666-31673.

Nwanjo, H. U. (2005). Efficacy of aqueous leaf extract Vernonia Amygdalina on plasma lipoprotein and oxidative status in Diabetic rat models. Nig. J. Physiol. Sci. 2005; 20: 3942.

Okochi, E; Watanabe, N; Shimada, Y; Takahashi, S; Wakazono, K; Shirai, T; Sugimura, T; Nagao, M. and Ushijima, T. (1999). Preferential induction of guanine deletion at $5^{\prime}$ GGGA-3' in rat mammary glands by 2-amino-1-methyl-6-phenylimidazo [4,5- b]pyridine. Carcinogenesis. 20: 1933-1938.

Schottenfeld, D. and Fraumeni, J. F. Jr. (1996). Cancer Epidemiology on Prevention. Oxford University Press, New York, NY, pp. 1-1521.
Schuette, S. A. and Richard, C. R. (1986). The effect of diets high in fat and/ or fiber on colonic absorbtion of $\mathrm{DMH}$ in the rat. Nutr. and Cancer. 8:257-266.

Sudhandiran Ganapasam (2013). Inibitory effect of luteolin on the status of membrane bound ATPases against azoxymethane-induced colorectal cancer. J. Chem. Pharm. Res. 5(6):123-127.

Sugimura, T. (1992). Multistep carcinogenesis: A 1992 perspective. Sci. 23: 603-607.

Zheng, W; Gustafson, D. R; Sinha, R; Cerhan, J. R; Moore, D; Hong, C.P; Anderson, K. E;

Kushi, L. H; Sellers, T. A. and Folsom, A. R. (1998). Well-done meat intake and the risk of breast cancer. J. Natl. Cancer Inst. 90: 1724-1729.

\section{How to cite this article:}

Augusta inegbedion and George E. Eriyamremu. 2016. ATPases in the colon of rats fed a Nigerian like diet supplemented with folate and bitter leaf (Vernonia amygdalina). Int.J.Curr.Res.Aca.Rev. 4(2): 316-327. doi: http://dx.doi.org/10.20546/ijcrar.2016.402.034 